\title{
PORNO-SYMBOLISM: A RESPONSE TO PROFESSOR MCCONAHAY
}

\author{
KATHARINE T. BARTLETT*
}

Any treatment of the symbolic politics of pornography must acknowledge the work done by feminists on this subject. Professor McConahay seems to recognize this fact, but in describing the feminist contribution, he marginalizes its significance and misses its critical insights. This comment sets forth these insights and how they bear on McConahay's analysis.

Feminists show considerable unity in their analyses of the symbolic politics of pornography. McConahay obscures, indeed denies, this unity by distinguishing four different feminist views on pornography (pp. 41-42). ${ }^{1}$ In fact, among the three positions McConahay is able to label "feminist," the differences are primarily tactical, relating more to what we should do about pornography than to our analysis of what it has done to us.

The essence of the feminist critique is that pornography states the terms upon which men relate to women, terms of domination by subject (male) to object (female). Not all pornography is necessarily offensive on this ground, ${ }^{2}$

Copyright $\odot 1988$ by Law and Contemporary Problems

- Professor of Law, Duke University School of Law. I am grateful to Neil Vidmar for reviewing my analysis of the social science data.

I note that no women were invited to give presentations at this conference on vice. Although I hesitate to take part in an enterprise that has assumed (unintentionally, I am certain) that the subjects of virtue and vice, privacy, abortion, and pornography could be adequately (or best) covered by men, I asked to be allowed this brief response in order to suggest the kind of perspective female participants might have added.

1. The only criteria McConahay brings to his judgment about what is feminist are an implied criterion that the author be a woman and the explicit criterion that she "has labeled herself a feminist" (p. 41 n.57). The first criterion is underinclusive. Men can be feminists; indeed, one of the most feminist, legal analyses of the pornography issue was written by a man. See Sunstein, Pornography and the First Amendment, 1986 DuKE L.J. 589. The second is overinclusive, as indicated I would contend by his inclusion as feminist the point of view that pornography is "another form of male entertainment that is not particularly harmful" (p. 42). It seems unlikely that his standards for determining what is a civil libertarian or a conservative (representing the two mainstream approaches to pornography) are as uncritical. One minimal definition of feminist is "someone who holds that women suffer discrimination because of their sex, that they have specific needs which remain negated and unsatisfied, and that the satisfaction of these needs would require a radical change. . in the social, economic and political order." Delmar, What is Feminism, in What IS Feminism: A REExamination 8, 8 (J. Mitchell \& A. Oakley eds. 1986).

2. Gloria Steinem, for example, finds it desirable to distinguish material that displays "mutually pleasurable, sexual expression between people who have enough power to be there by positive choice," from pornography that features "violence, dominance, and conquest" or that attempts to convince women that "pain and humiliation ... are really the same as pleasure." Steinem, Erotica and Pornography: A Clear and Present Difference, in Take Back the Night: Women on Pornography 35, 37 (L. Lederer ed. 1980). This differentiation represents the traditional distinction between erotica (consensual sexual relationships between co-equals) and thanatica (sexual relationships that are unequal and coerced). See Tong, Women, Pornography, and the Law, Academe, Sept./Oct. 1987, at 14 [hereinafter Tong]. A number of other feminists, as well, have argued that some pornography is 
but the critique speaks to the "preponderance of the characterizations of women in pornography as anonymous, panting playthings that men liberally exploit for sexual self-gratification and any self-enhancing concomitant thereof." 3 The overwhelming message of this predominant form of pornography is that women are objects of pleasure for men, to be possessed and violated by them. Pornography constructs the reality of sexual relations so that men expect, and women accept, male domination and female submissiveness. In this way, pornography is not an extreme or peripheral form of expression about sexual practices; it represents, instead, the epitome of excitement, what we would all want if only we could get it. Pornography is ideal sex. ${ }^{4}$

Central to the feminist critique is the concept of symbolism, but not symbolism of the sort described by McConahay. McConahay describes as "symbolic" an issue "on which people take sides not on the basis of their self or economic class interest, but on the basis of what the issue symbolizes to them" (p. 43). Thus, while some issues implicate our economic or "self". interests, other issues relating to our lifestyle choices or our religious or moral values implicate our "symbolic" interests (p. 43). If we can satisfy the symbolic interests that different groups of people have in the issues raised by pornography, McConahay suggests, we can go a long way toward resolving these issues. Ultimately, he concludes that "some version of the status quo

\footnotetext{
"good" pornography, which can enlarge our notions of sexual expression in healthy, beneficial ways. See, e.g., West, The Feminist-Conservative Anti-Pormography Alliance and the 1986 Attomey General's Commission on Pornography Report, 4 AM. B. Found. REs. J. 681, 690-96 (1987); Dunlap, Sexual Speech and the State: Putting Pornography in Its Place, 17 Golden Gate L. Rev. 359 (1987); Hollibaugh, Desire for the Future: Radical Hope in Passion and Pleasure, in Pleasure and Danger: Exploring Female Sexualtry 401 (C. Vance ed. 1984). Some feminists believe, on the other hand, that given the overpowering images of sexual relationships as subject/object relationships in our society, including those provided by pornography, it is unlikely that there is any such thing as consensual sexual relationships. See C. Mackinnon, Feminism Unmodified: Discourses on Life and Law 60-61 (1987). See also D. Russell, The Politics of Rape 261 (1975) (Much of what passes for normal hetereosexual intercourse is close to rape.).
}

3. Zillman \& Bryant, Pornography, Sexual Callousness and the Trivialization of Rape, $32 \mathrm{~J}$. of Communication, Autumn 1982, at 10, 12 [hereinafter Zillman \& Bryant]. The Meese Commission also found that "forms of degradation," meaning "material that, although not violent, depicts people, usually women, as existing solely for the sexual satisfaction of others, usually men, or that depicts people, usually women, in decidedly subordinate roles in their sexual relations with others, or that depicts people engaged in sexual practices that would to most people be considered humiliating" represents the "largely predominant proportion of commercially available pornography." U.S. Dep't of Justice, AtTorney General's Commission on Pornography: Final RePORT 331-32 (1986). See also Smith, Sexual Aggression in American Pornography: The Stereotype of Rape, cited in Bart \& Jozsa, Dirty Books, Dirty Films, and Dirty Data, in TAKe Back the Nighr: Women on PoRNOGRAPHY, supra note 2 , at 204, 213-14 (substantiating the prominence in pornography of the theme of the transformation of female terror and humiliation during forced sex into physical cooperation and eventually intense longing for further abuse).

4. See C. Mackinnon, supra note 2, at 149; S. Brownmiller, Against Our Will: Men, Women and Rape 394 (1975); K. Barry, Female Sexual Slavery 213 (1979). This critique is shared not only by radical feminists who advocate censorship of a broad range of pornographic materials but also by those who oppose censorship. See, e.g., Diamond, Pornography: Image and Reality, in Women AGaInst Censorship 40 (V. Burstyn ed. 1985); Willis, Feminism, Moralism, and Pornography, in Powers of Desire: The Politics of Sexuality 460 (A. Snitow, C. Stansell \& S. Thompson eds. 1983). 
might be the best approach" to satisfying the symbolic needs of all sides of the controversy (p. 67).

In speaking of symbolism, the feminist critique uses an entirely different level of discourse than that used by McConahay. Within feminist discourse, symbolism is not an operational term used to categorize discrete interests or motivations of individuals, but rather an explanatory concept used to describe a process of culture formation. The feminist critique rejects the notion that symbolism is an independent force or an interest distinct from other interests. It insists that a society is defined or constituted by its symbols. Symbols represent who we are, our "self"'-interests, and how we relate to one another. Symbols are political in that they define relations of power between individuals. Symbols do not merely satisfy distinct, abstract human needs; symbols create and define human needs.

Because symbols work invisibly to construct reality, any harm in that reality is itself invisible. Thus, in the case of porno-symbolism, society does not think to question the reality that sex is for men; that women serve men; that control is erotic; that force and violence are stimulating; that domination is sexy. It may question some forms of force and violence, but in drawing lines it in fact affirms the central reality; in rendering unacceptable the most extreme forms of pornography, it legitimizes the remainder. ${ }^{5}$

McConahay states that "pornography is a ... problem for a small. . . minority of Americans, somewhat of a problem for a larger minority, something to be enjoyed by a larger, less intense minority, and a matter of ambivalence for most Americans" (p. 32). This statement not only lacks any credible factual basis, ${ }^{6}$ but is naive as to the fundamental nature of the harms caused by pornography. What feminists have begun to understand is that not

5. McConahay completely ignores this phenomenon. Thus he claims that screening boards to review pornography bear some necessary symbolic relationship to the purpose of "uphold[ing] traditional morality and prevent[ing] the degradation of women" (p. 67). First of all, whether such a symbolic purpose is served will depend upon what society understands such boards to be disapproving (or at least pretending to disapprove). But more to the point, an important symbolic effect of a review process is to legitimize or affirm the norms of sexual relationships contained in the (relatively large percentage of) pornography it does not proscribe.

6. McConahay's support for this conclusion comes from a number of public opinion polls taken since 1965 (pp. 32-36). In these polls, few respondents named pornography when asked to name "the most serious problem" or "the two or three most serious problems facing the country today." Given that the other problems identified by the surveys included violent street crime, drugs, the Vietnam war, racial conflict, environmental pollution, the economy, and nuclear war, the most noteworthy aspect of these surveys, to me, is that so many respondents chose pornography. In one 1983 poll, $4.6 \%$ of those surveyed identified pornography as "the most serious problem today in your area in California," among such other problems as violent street crime and cocaine. (p. 34). In another poll taken in 1986 and 1987 , although only $1.6 \%$ of respondents picked pornography ( $p$. 34 ), another $19.4 \%$ chose sexually abusing children, making a total of $21 \%$ who chose either one or the other. This additional information is reported in $\mathrm{J}$. McConahay, Pornography and Public Opinion: How Many and Who Would Ban What? 7 (1988) (Working Paper, Institute of Policy Science and Public Affairs, Duke University). As McConahay himself acknowledges, if respondents had been asked to name a larger number of problems, pornography might well have been reported with more frequency (p. 34). These studies do not seem to support the conclusion of some of the researchers that pornography is "not a major concern of most Americans" (p. 34) or McConahay's conclusion that the issue of pornography is a "matter of ambivalence for most Americans" (p. 32). 
only are the specific victims of criminal sexual violence inspired by pornography harmed, but also all other women who are affected by the sexual reality defined by pornography. That "small minority" of Americans who recognize the harm of pornography, indeed, may actually be the ones the least harmed by pornography. More vulnerable are those who do not know to question the terms of sexual relationships with which they are presented, including both those who come in contact, especially on sexual terms, with that "larger minority" who enjoys pornography and those who are affected in more subtle ways by the pervasiveness, and perversity, of the messages of sexual domination which form our notions of sexual norms. ${ }^{7}$

Most all of the studies cited in McConahay's article purport to demonstrate the harmlessness of pornography ${ }^{8}$ but instead affirm how deeply hidden its assumptions are. Studies cited by McConahay, for example, claim to have shown that exposure to pornography "neither significantly affected attitudes toward sex nor produced calloused sexual attitudes toward women." (p. 56-57). The validity of such findings, however, depends upon what is meant by "sex" or "calloused sexual attitudes." 9 To the extent the feminist critique is accurate, that is, that the terms of hierarchical sexual domination portrayed in pornography have set the standards for normal or socially acceptable sexual relationships between men and women, behaviors increased by exposure to pornographic material that depicts these behaviors simply will not be reported as aberrant. ${ }^{10}$

7. McConahay recognizes only parenthetically and dismissively that pornography may in some sense harm women in this more general, and pervasive, sense. He notes, for example, that "[n]onviolent, mildly arousing pornography (Playboy nudes), though possibly degrading to women, has been found to reduce aggressive tendencies in previously angered males." (p. 55, emphasis added). Similarly, he writes that " $[s]$ tudies commissioned by the 1970 Commission on Pornography found that short-term exposure to nonviolent sexually explicit material, though possibly showing degrading images of women, neither significantly affected attitudes toward sex nor produced calloused sexual attitudes toward women." (pp. 56-57, emphasis added, footnotes omitted). The studies referred to, incidentally, have been contradicted by subsequent studies. See, e.g., Donnerstein, Pornography: Its Effect on Violence Against Women, in Pornography and Sexual Aggression 53 (N. Malamuth \& E. Donnerstein eds. 1984); Zillman \& Bryant, Effects of Massive Exposure to Pornography, in PornograPhy and Sexual Aggression, supra, at 115.

8. Of the studies cited by McConahay, the most notable exception is a study by Dolf Zillman and Jennings Bryant. See Zillman \& Bryant, supra note 3, at 10.

9. Likewise, several of the studies cited by McConahay (such as those done by Mosher and Kutchinsky) to support the conclusion that pornography does not have "damaging effects" were commissioned by the United States Commission on Obscenity and Pornography. This Commission defined as its research goal the investigation of the relationships between the use of "erotic" material and "antisocial" or "socially acceptable" behavior. See THE RePORT of THE Commission on OBSCENITY AND PORNOGRAPHY 148 (1970). Once again, these research categories merely beg the question.

10. At the heart of the feminist critique is the observation that even women will not consider behaviors legitimized through pornography as aberrant. Some evidence for this point is provided from the Danish experience in liberalizing pornography laws. Kutchinsky reports that after the Danish laws were liberalized, "fewer young women tended to report sex crimes... [because of] the development of a more 'tolerant view of minor sexual interferences' on the part of the young women." Kutchinsky, The Effect of Easy Availability of Pornography on the Incidence of Sex Crimes: The Danish Experience, 29 J. of Soc. Issues, No. 3, at 163, 170 (1973).

A statement by a woman interviewed in a study by Diana Russell that attempted to determine the extent to which men exposed to pornography tried to get women to do what they had seen is 
One study cited for the proposition that pornography results in "increased love ... [for one's] intimate partners ..." (p. 58), " helps to demonstrate the problem dramatically. Although this study purports to measure increased caring between mates, it actually attempts to measure only increased "caring" by men toward women. ${ }^{12}$ The very research plan thereby reinforces the notion that in matters of sex and love, it is appropriate to think of men as actors, women the acted upon. ${ }^{13}$ More to the point, the "increased caring" is measured by scales related only to how the participants (all male) rated female attractiveness, receptivity, and cooperativity to sexual overtures after exposure to pornography. ${ }^{14}$ The proposition of increased caring is thus established according to the effect of pornography on male perceptions of female availability and receptivity to men's sexual needs. It is little wonder that the study concluded that pornography exerted a beneficial influence on sexual relations.

Another study is cited by McConahay for its findings that pornography does not increase calloused sexual attitudes by men toward women (pp. 5657). ${ }^{15}$ Again, far from disproving the feminist insight that pornography defines appropriate sexual behaviors, the study's findings are just as easily explained by it. According to the study, the attitudes of men exposed to pornographic films did not become more sex-calloused toward women than before viewing the films, and sex-calloused men did not increase their sexual behaviors after viewing the films. ${ }^{16}$ Even if the criteria for "sex-callousness" do not already describe socially acceptable attitudes and behaviors, ${ }^{17}$ the most the study may demonstrate is that the indoctrination that already takes place

poignant first-hand testimony on this phenomenon: "My husband enjoys pornographic movies. He tries to get me to do things he finds exciting in movies. . . Also, I was always upset with his ideas about putting objects in my vagina, until I learned this is not as deviant as I used to think. He used to force me or put whatever he enjoyed into me." Russell, Research on How Women Experience the Impact of Pornography, in Pornography and Censorship 213, 215 (D. Copp \& S. Wendell eds. 1983). McConahay's final comment on this issue seems to be critical of women who resist: "It should be added that not all women are angered by the suggestion to try out new things" (p. 59 n.209).

11. The study is reported in Dermer \& Pyszczynski, Effects of Erotica Upon Men's Loving and Liking Responses for Women They Love, 36 J. Pers. \& Soc. Psych. 1302 (1978) (hereinafter Dermer \& Psyzczynski].

12. Id. at 1303 .

13. In explaining why pornography audiences want "to see action, not plot or character development," that "[they are] almost exclusively male" (p. 49), and in implying that men are more likely to be aroused by pornography than women (p. 54), McConahay does not question the basic notion that sex (and thus pornography) is for men, not women.

14. Dermer \& Psyzczynski, supra note 11, at 1304. Still another problem with the study is that the stimuli used by the researchers was erotica rather than thanatica. Id. at 1303-04. Finally, the purpose of the study was to validate a conceptual scheme for describing loving and liking, not to determine the causal effects of pornography on loving and liking. Id. at 1302 .

15. This study is reported in Mosher, Psychological Reactions to Pornographic Films, in 8 TeChnical Reports of the Commission on Obscenity and Pornography 255 (1971) [hereinafter 8 Technical. REPORTS].

16. Id.

17. Among the questions to which affirmative answers indicated sex-callousness under the study (followed by percentage of male subjects answering "yes") are: "that most woman [sic] require masculine dominance (e.g., "most women like to be dominated and sometimes humiliated" [58\%]; "Pickups should expect to put out" [53\%]; "A woman doesn't mean 'No' unless she slaps you" [39\%]; and "that sex aggression is justifiable (e.g., "_-teasers should be raped" [51\%]. Id. 
with respect to male sexual attitudes so nearly reflects the attitudes suggested in pornography as to not be enhanced by exposure to pornography. ${ }^{18}$

In observing that "pornography has the potential . . . to strengthen the family" (p. 58), McConahay further fails to take account of the feminist insight that pornography has itself set the sexual norms which are claimed to be strengthened. That couples use pornographic videos "as a means of sexual arousal before making love," that "marriage counsellors use erotica . . . to help individuals and couples improve their sex lives," and that "males reported increased love for their intimate partners after reading pornographic passages from magazines" (p. 58, footnotes omitted) would seem to confirm that pornography helps to set the terms upon which men expect and women accept certain sexual behaviors. If women comply more readily with what men want as a result of pornography, (male) researchers naturally will report favorably on its effects.

Feminists do disagree about the degree to which pornography should be regulated, that is, what we should do about the harm of pornography. These are largely disagreements about the importance of other competing values, especially those reflected in the first amendment. Catharine Mackinnon and Andrea Dworkin, for example, insist that the first amendment is a male tool which enables men to speak to keep women silent and in their place; in their view it protects no values that women should embrace. ${ }^{19}$ Other women view the first amendment more favorably, some because they fear controls on speech are more likely to be used to restrict women's speech than men's, ${ }^{20}$ others because they find speech controls counterproductive in building the kind of society they seek. ${ }^{21}$ These are disagreements not about whether

18. The author of the study himself accepts that sex-calloused attitudes form an ordinary part of the socialization of the adolescent male. See Mosher, Sex Callousness Toward Women, in 8 Technical. REPORTS, supra note 15 , at 313 .

Another explanation for the results of the study is offered by Diana Russell, who suggests that the pornography used in the study may have been "better-than-average" erotica rather than pornography. See Russell, Pornography and Violence: What Does the New Research Say?, in TAKE BACK THE Night: Women on Pornography, supra note 2, at 218, 219.

19. C. MacKinnon, supra note 2, at 206-13; Dworkin, Against the Male Flood, 8 Harv. Women's L.J. 1 (1986); Dworkin, For Men, Freedom of Speech; for Women, Silence Please, in TAKe Back THE Night: Women on Pornography, supra note 2, at 256.

20. Morgan, Pormography: Who Benefits, in Take Back the Night: Women on Pornography, supra note 2, at 134, 137; Duggan, Hunter \& Vance, False Promises: Feminist Antipornography Legislation in the U.S., in Women Against Censorship, supra note 4, at 130; Burstyn, Political Presidents and Moral Crusades, in Women Against Censorship, supra at 4, 17-20; Burstyn, Beyond Despair: Positive Strategies, in Women Against Censorship, supra at 152, 158-61.

21. Dunlap, supra note 2, at 366-78 (ban on pornography incompatible with much needed, clearer public expression in such areas as sex education, elimination of sex-role stereotyping, sexual preference, pregnancy, AIDS, and the elimination of violence in sex); Hollibaugh, supra note 2, at 401-09 (censoring pornography based upon a single "correct" notion of sex antithetical to feminists" interests in more expanded sexual options); Tong, supra note 3, at 14, 14-22; Valverde, Weir \& Tarills, Thrills, Chills and the "Lesbian Treat" or the Media, the State and Women's Sexuality, in Women Against Censorship, supra note 4, at 99 (seeking source of general sexual pluralism). A few scholars have argued that regulation of pornography that sexualizes violence is consistent with the first amendment. See, e.g., Sunstein, supra note 1. See also Longino, Pornography, Oppression, and Freedom: A Closer Look, in TAke Back the Night: Women on Pornography, supra note 2, at 40, 49-53 (First amendment should not be interpreted to protect pornography.). 
pornography is (or can be) harmful, but about what kind of world we want and what will work best to bring about this world.

In the end, I may agree with McConahay's conclusion that pornography should not be further regulated by the law. But I disagree vigorously with the argument upon which he bases this conclusion-that pornography is really not so bad after all. If social science has not yet proven the elusive truths of the feminist critique, it certainly has not disproved them either; indeed, it has hardly begun to ask the right questions. The feminist critique must be taken seriously. If it is not, social scientists will go on conducting research that proves nothing (or, worse, proves falsehoods), and the legal and moral debate on pornography will proceed based upon inadequate, and inaccurate, factual premises. Fully comprehended, the critique should lead us to a broader understanding of social harm, a fuller normative debate about appropriate models of sexual behavior, and more creative alternatives to the inequalitarian norms that make most forms of pornography socially and morally, if not legally, unacceptable. 
